\title{
Defatted chia flour improves gluten-free bread nutritional aspects: a model approach
}

\author{
Marci EWERLING ${ }^{1}$, Nádia Cristiane STEINMACHER ${ }^{2}$, Maristela Raupp dos SANTOS 3 , \\ Daneysa Lahis KALSCHNE ${ }^{1 *}$ (D), Nilson Evelázio de SOUZA ${ }^{4}$, Flora Miranda ARCANJO ${ }^{1}$, \\ Aloisio Henrique Pereira de SOUZA ${ }^{5}$, Angela Claudia RODRIGUES ${ }^{1}$
}

\begin{abstract}
The gluten is a protein associated with a numerous food allergy cases. As the gluten-related disorders relates is increasing, the demand for gluten-free breads (GFB) has been also increasing. The aim of this study was to obtain a GFB with increased nutritional aspects and sensorially accepted. A Central Composite Rotatable Design (CCRD) $2^{3}$ was employed in order to choose the ideal proportions of partially defatted chia flour (PDCF) (1.23 to 24.77\%), hydroxypropylmethylcellulose gum (HPMC) ( 0.00 to $2.51 \%)$, and Xanthan gum (XG) (0.00 to $2.51 \%)$ in a mixed flour used in GFB. The responses evaluated in GFB were: total lipids, protein, ash, carbohydrate, and omega-3 content, specific volume, $\mathrm{L}^{\star}$, $\mathrm{a}^{\star}$, and $\mathrm{b}^{\star}$. The sensory acceptance was also evaluated. PDCF was the variable with higher effects in nutritional aspects; in high levels PDFC increase the protein, ash, and omega- 3 content and decrease carbohydrate content of GFB. Although PDCF addition in the higher proportions negatively influenced the color parameters - decrease $\mathrm{L}^{*}$ and increase $\mathrm{a}^{*}$ - the mixed flour with $20 \%$ of PDCF, $0.51 \%$ of HMPC and $0.51 \%$ of XG added to GFB, was the most accepted for overall acceptance.
\end{abstract}

Keywords: acceptance; Central Composite Rotatable Design; hydroxypropylmethylcellulose omega-3; Salvia hispanica L; xanthan gum.

Practical Application: Gluten-free bread elaboration with additional nutritional aspects.

\section{Introduction}

Gluten is a complex water-insoluble proteins (gliadin and glutenin) derived from wheat, rye, and barley. Among the gluten-related disorders, the celiac disease, allergy to wheat, and sensitivity to non-celiac gluten can be mentioned. In the three disorders, the treatment includes the exclusion of gluten from the diet (Resende et al., 2017). Reports show a growing interest of Brazilians for gluten-free products. Among all functional, natural, or healthy-profile food categories, gluten-free products have the highest growth forecast in the country until 2022, with an estimated increase in sales between $35 \%$ and $40 \%$ per year (Época, 2018). Gluten-free breads (GFB) is an option for consumers with some gluten-related disorders, because it is part of daily eating habits. The development of a balanced GFB enriched with nutrients is an excellent option to avoid other diseases linked to the lack of bread in the diet. This is associated with the fact that, individuals afflicted with gluten-related disease, often present low absorption of nutrients and/or available products do not contain the necessary nutrients in the quality or quantity required to maintain a balanced diet (Alencar et al., 2012).

The chia (Salvia hispanica L.) is an option for gluten-free formulation products with high nutritional value (Zettel \& Hitzmann, 2018). Chia nutritional properties were mainly associated with its high content of protein (18 to $25 \%$ ), fiber
(30 to $35 \%$ ), and lipids (30 to $38 \%$ ) - about $64 \%$ of total lipids corresponds to omega-3 (Brites et al., 2019; Chaves et al., 2018; Huerta et al., 2018; Silva et al., 2016). This fatty acid group (alpha-linolenic C18:3 and derivatives DHA and EPA) is essential for human being, with anti-inflammatory properties, effects in triglycerides, cardiovascular disease, hypertension, and platelet aggregation reduction (Faccim et al., 2016). The chia seeds also have a high content of minerals, including $\mathrm{Ca}, \mathrm{P}, \mathrm{K}, \mathrm{Mg}$, $\mathrm{Fe}$, and $\mathrm{Zn}$ (Silva et al., 2016), and a reduced energy value (Chaves et al., 2018; Veggi et al., 2018).

Gluten-free flours and starches are deficient in structural proteins and form inferior molecular networks in dough (Crockett et al., 2011). Additionally, the nutritional quality of GFB is mostly low (Zettel \& Hitzmann, 2018). The incorporation of chia, especially in the preparation of gluten-free foods, is promising due to the aforementioned technological and nutritional characteristics (Huerta et al., 2016). Due to the excellent dietary properties of chia, some studies have been developed in order to prove the nutritional enrichment in different food products (Costantini et al., 2014; Huerta et al., 2017, 2018; Zettel \& Hitzmann, 2018). Additionally, the defatting of chia it is interesting to obtain partially defatted chia flour (PDCF) with

Received 07 Jan., 2019

Accepted 03 Dec., 2019

${ }^{1}$ Programa de Pós-graduação em Tecnologia de Alimentos, Universidade Federal Tecnológica do Paraná - UTFPR, Câmpus Medianeira, Medianeira, PR, Brasil

${ }^{2}$ Departamento de Alimentos, Universidade Federal Tecnológica do Paraná - UTFPR, Câmpus Medianeira, Medianeira, PR, Brasil

${ }^{3}$ Departamento de Química, Universidade Federal Tecnológica do Paraná - UTFPR, Câmpus Medianeira, Medianeira, PR, Brasil

${ }^{4}$ Departamento de Química, Universidade Estadual de Maringá - UEM, Maringá, PR, Brasil

${ }^{5}$ Departamento de Alimentos, Instituto Federal do Mato Grosso do Sul - IFMS, Coxim, MS, Brasil

*Corresponding author: daneysa@hotmail.com 
reduced oil content, avoiding problems during processing and balancing the lipid content.

In order to improve GFB technological properties the hydrocolloids are typically added for additional water binding, increasing softness (Wang et al., 2017). In GFB, the hydrocolloids are tested to increase gas retention and loaf volume. Hydroxypropylmethylcellulose gum (HPMC) suffers a thermal reversible gelation; gelling in cool water, becoming amorphous upon heating, and reverting to a gel after cooling. Xanthan gum (XG) forms high-viscosity pseudoplastic material, thus is very common in commercial GFB (Crockett et al., 2011). The aim of this study was to obtain a GFB with increased nutritional aspects and sensorially accepted. A Central Composite Rotatable Design (CCRD) was employed in order to choose the ideal proportions of PDCF, HPMC, and XG in a mixed flour used in GFB.

\section{Materials and methods}

\subsection{Ingredients and gluten-free bread elaboration}

The rice flour, sweet manioc flour, potato starch, PDCF, sugar, salt, eggs, olive oil, water, Saccharomyces cerevisiae yeast, HPMC, and XG were acquired at a local market of Medianeira, Parana, Brazil. The PDCF was obtaining after to remove the oil of crude chia by cold pressing and hemmer grind the resultant mass (14-16 mesh) (Giroil, Santo Ângelo, RS).

A GFB control formulation was elaborated based on the Brazilian Celiac Association (ACELBRA) descriptions. Preliminary tests were carried out in order to define a mixed flour (145 g), composed by rice flour $(75.4 \mathrm{~g})$, potato starch $(52.2 \mathrm{~g})$, and sweet cassava flour $(17.4 \mathrm{~g})$. The other ingredients were calculated based on total mixed flour (145 g; 100\%) as following: sugar (15.0 g), vinegar (4.0 g), salt (1.5 g), egg (50.0 g), olive oil (18.75 g), water (50.0 g), and Saccharomyces cerevisiae yeast $(2.5 \mathrm{~g})$. All the ingredients were weighed and the mixed flour, sugar, and salt were manually mixed for $30 \mathrm{~s}$. The mixture was added to the egg, olive oil, and water; and blending in a food mixer (Black \& Decker 400W, Uberaba, Minas Gerais), with a medium dough mixer attachment on speed 2 for $1 \mathrm{~min}$. All GFB added of PDCF, HPMC, and XG (Table 1) were added of $80.0 \mathrm{~g}$ of water ( $30.0 \mathrm{~g}$ more than control). The yeast was added to the dough and mixed at speed 5 for $2 \mathrm{~min}$. The dough was molded into rectangular stainless-steel baking pan greased with soybean oil, kept at controlled humidity for $50 \mathrm{~min}$ at $37^{\circ} \mathrm{C}$. The baking was performed in a pre-heated industrial oven at $180^{\circ} \mathrm{C}$ for $25 \mathrm{~min}$. The breads were removed from the pans after cold and stored in polythene packages inside polypropylene boxes.

\subsection{Experimental design}

A CCRD was used to develop a mixed flour employed in GFB samples elaboration ( $2^{3}$ plus star configuration with 6 central points, total 20 runs). The influence of the variable's percentage of PDCF, HPMC, and XG on the responses total lipid, protein, ash, carbohydrate, and omega- 3 content, specific volume, and color parameters $\left(\mathrm{L}^{\star}, \mathrm{a}^{*}\right.$ and $\left.\mathrm{b}^{*}\right)$ were evaluated in GFB (Table 1). The percentage of each variable was calculated taking in account the percentage of replacement of mixed flour (considering mixed flour $=100 \%$ ). Additionally, a control sample without PDCF, HPMC, and XG was elaborated.

\subsection{Proximate composition and fatty acid composition}

The moisture and volatile matter content (method no. 925.10), crude protein (method no. 920.87, nitrogen-converting factor of 6.25), and ash (method no. 923.3) was determined according the Association of Official Analytical Chemists (1995). Total lipids were extracted and determined according to Bligh \& Dyer (1959), and total carbohydrate was calculated by difference. The results were expressed in $\mathrm{g} 100 \mathrm{~g}^{-1}$ (dry basis).

The GFB lipids were derivatized and converted into fatty acid (FA) methyl esters according Hartman \& Lago (1973) to determinate FA composition. The FA methyl esters were injected $(1 \mu \mathrm{L})$ in a gas chromatograph equipped with an automatic sampler with a flame ionization detector (Clarus 680, Perkin Elmer, Beaconsfield, UK) and fused silica capillary column (Select Fame 7420, 100 m, $0.25 \mathrm{~mm}$ and $0.25 \mu \mathrm{m}$ i.d., Agilent J\&W, Santa Clara, USA). A helium carrier gas $\left(1.30 \mathrm{~mL} \mathrm{~min}^{-1}\right)$, hydrogen $\left(45 \mathrm{~mL} \mathrm{~min}^{-1}\right)$, synthetic air $\left(450 \mathrm{~mL} \mathrm{~min}^{-1}\right)$, and a 1:50 split were employed. FA identification was based on the comparison of retention times with those of the methyl esters from the standard mixture containing geometric isomers of linoleic acid and alpha-linolenic acid (Sigma-Aldrich ${ }^{\circledR}$, Saint Louise, USA). The results were expressed as a relative percentage of the identified FA.

\subsection{Specific volume and color parameters}

Specific volume of the GFB was determined by the ratio between volume $(\mathrm{mL})$ and mass of the bread $(\mathrm{g}), 24 \mathrm{~h}$ after cooking. The specific volume was determined through the millet-seed displacement method (El-Dash et al., 1982). The results were expressed in $\mathrm{mL} \mathrm{g}^{-1}$.

The lightness $\left(\mathrm{L}^{*}\right)$, coordinate green-red $\left(\mathrm{a}^{*}\right)$, and blue-yellow $\left(b^{*}\right)$ were determined in the center of GFB using a colorimeter (CR400, Konica Minolta, New Jersey, USA) with an integrating sphere and $45^{\circ}$ viewing angle (lighting $\mathrm{d} / 45$ and illuminating $\mathrm{D}$ ) $24 \mathrm{~h}$ after baking.

\subsection{Data analysis}

All results were determined in triplicate and expressed by mean \pm standard deviation. The CCRD data were assessed using analysis of variance $($ ANOVA $)(\mathrm{p} \leq 0.05)$ by Experimental Design procedure of Statistica 8.0 software. The effect of the PDCF, HPMC, and XG were evaluated for each response individually. The adequacy of the models generated by the CCRD was assessed $(\mathrm{p} \leq 0.05)$. In order to define the best GFB formulation, the responses were optimized using the Response Desirability Profiling procedure. The global desirability function was determined regarding the nutritional aspects; the goal was to maximize the protein, ash, and omega- 3 content and minimize the carbohydrate. The procedure computes a desirability value $(d i)$ of each response with significant effect with $d i$ value ranges from 0 to $1 ; d i=1$ means the ideal case and $d i=0$ means that at least one response falls outside the desirable limits. 


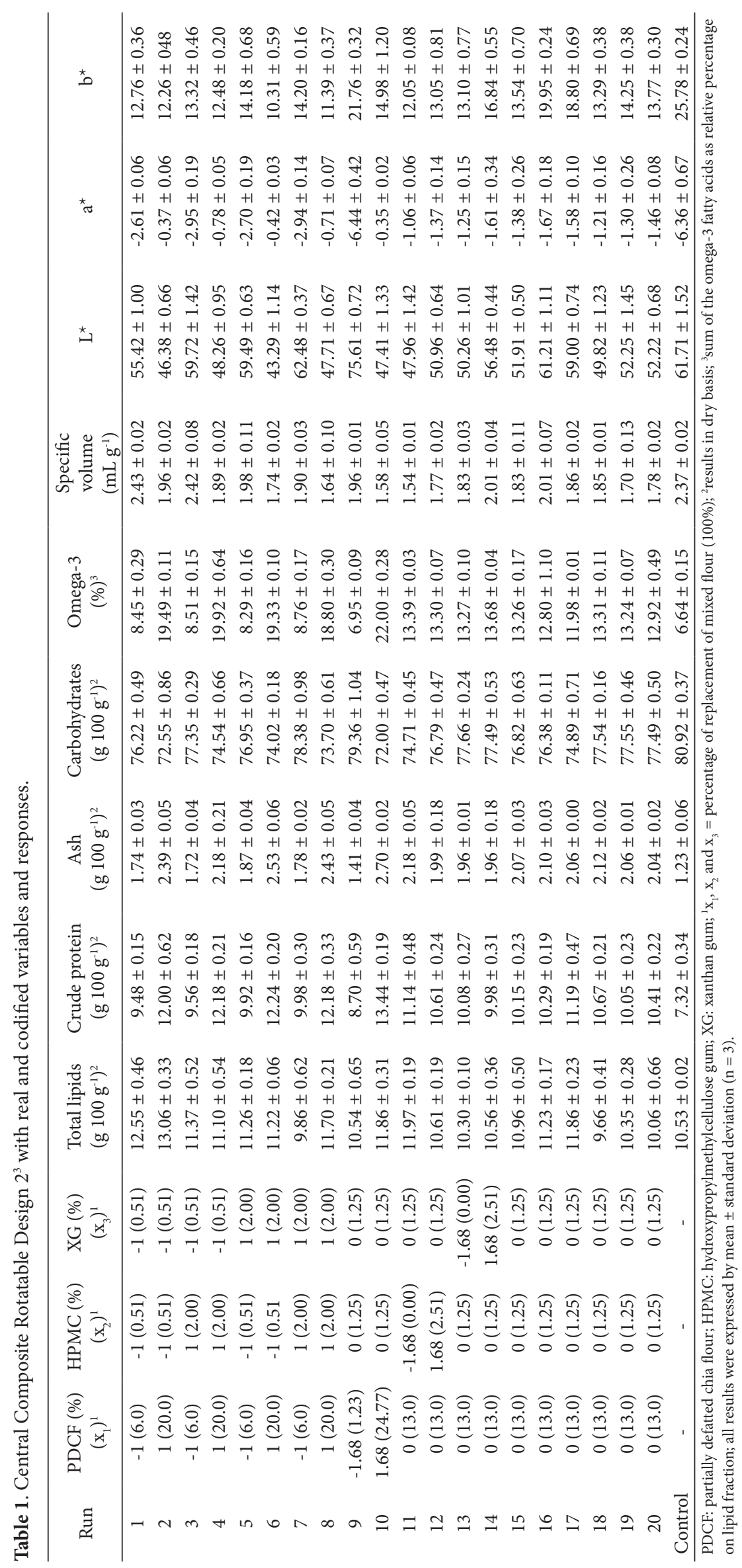




\subsection{Acceptance test}

For acceptance tests, three GFB samples were selected and prepared $24 \mathrm{~h}$ before the analysis. Based on the desirability results, run 2 (20.00\% PDCF, 0.51\% HPMC, and 0.51\% XG) was chosen as a great possibility of incremented nutritional aspects. In contrast, run 1 (6.00\% PDCF, 0.51\% HPMC, and 0.51\% XG) was chosen because its nutritional composition was inferior than run 1, and the HPMC and XG was in the same range. Additionally, the control was also evaluated for comparison. Tests were conducted in an individual booths, under white light. GFB slices were cut in 4 similar portions $(\cong 30 \mathrm{~g})$ and served in a white plastic plate codified with three randomized digits in a monadic way. Consumers cleaned their palate with water before and between samples. The participants were university students, teachers, and employees, all regular bread consumers and the study was authorized by the Ethics Committee of UTFPR (1.017.363). The panel of 116 consumers evaluated the samples using a 9-point hedonic scale with verbal terms $(1=$ disliked extremely, 5 = neither liked, nor disliked, 9 = like extremely) for attributes color, aroma, texture, flavor, and overall acceptance. The data were evaluated by main effects ANOVA and Tukey test ( $\mathrm{p} \leq 0.05)$ using the Statistica 8.0 software.

\section{Results and discussion}

The content of total lipid of control GFB was in the range

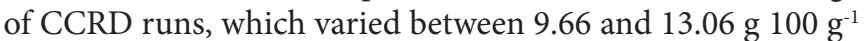

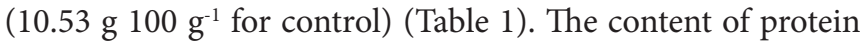

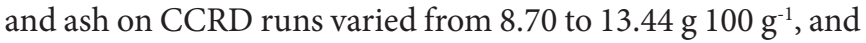

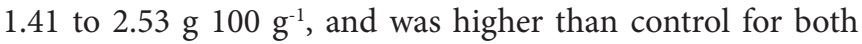

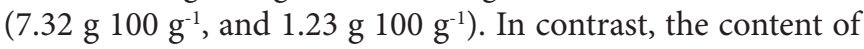
carbohydrates on CCRD runs was lower than control and varied

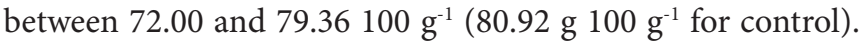
The omega- 3 relative percentage varied from 6.95 and $22.00 \%$ in CCRD runs and was higher than control (6.64\%). The specific volume of control $\left(2.37 \mathrm{~mL} \mathrm{~g}^{-1}\right)$ was in the range of CCRD runs, between 1.54 and $2.43 \mathrm{~mL} \mathrm{~g}^{-1}$. The $\mathrm{L}^{*}$ and $\mathrm{a}^{*}$ for control (61.71 and -6.36) was also in the range of CCRD runs, from 43.29 and 62.48 , and -0.35 and -6.44 . In contrast, the $b^{*}$ of control (25.78) was higher than CCRD runs, which varied between 10.31 and 21.76 .

In general, data availability for the composition of GFB only added of chia is also limited. GFB added of chia in different forms - seeds, flour, mucilage - and proportions, mixed with other ingredients such potato, buckwheat, soy, and rice showed

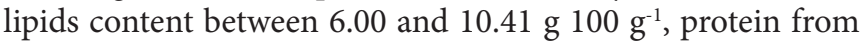

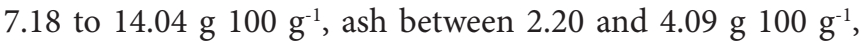

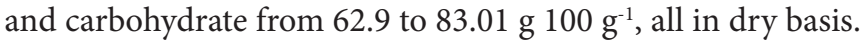
The specific volume varied between 1.28 and $2.32 \mathrm{mg} \mathrm{L}^{-1}$, $\mathrm{L}^{\star}$ from 45.9 to 71.92 , $\mathrm{a}^{*}$ between 0.01 and 4.19 , and $\mathrm{b}^{*}$ from 4.64 to 21.33 . The omega-3 content in the present article was superior compared with GFB added of whole chia flour and chia seeds (6.75 and $6.74 \%$ of relative percentage on lipid fraction) (Costantini et al., 2014; Huerta et al., 2017, 2018; Pereira et al., 2013; Steffolani et al., 2014). Literature data comparison shows that, in general, proximal composition, omega-3, specific volume, and color parameters of the GFB elaborated by CCRD runs are in the range described for GFB with chia described by other authors.

No significant effects of the variables in the range studied were observed for total lipid ( $p>0.05$ ) (Table 2). It was probably associated with the defatting process applied in PDCF, obtaining

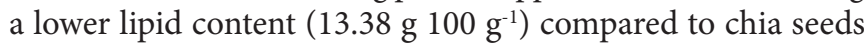
(30 to $38100 \mathrm{~g}^{-1}$ ) (Ewerlin et al., 2018; Silva et al., 2016). For other two variables, protein and omega- 3 content, it was observed a similar behavior: positive effects of the linear and quadratic terms of PDCF $\left(\mathrm{x}_{1}\right)$. This was expected because PDCF had a high

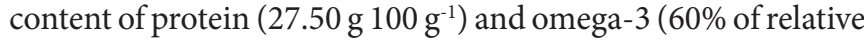
percentage on lipid fraction). According to Silva et al. (2016) chia seeds nutritional aspects were mainly associated with its high content of protein (18 to 25\%) and omega-3 - about $64 \%$ of chia seeds total lipids corresponds to linolenic acid (omega-3).

Carbohydrate content and specific volume showed similar models, with negative effect of linear PDCF term $\left(\mathrm{x}_{1}\right)$. An additional negative effect of quadratic term of PDCF $\left(\mathrm{x}_{1}\right)$ was observed for carbohydrate content (Table 2). The reduce of carbohydrate from diet is a tendency, especially because the refined carbohydrates are the mainly contributor of obesity (Assaad et al., 2019). Regarding the specific volume, the GFB dough expansion is hampered because they did not contain the gluten network that ensure expansion through the entrapment of gas formed by fermentation (Huerta et al., 2017). The ash content and $\mathrm{a}^{\star}$ hadsignificantly positive effects of linear term of $\operatorname{PDCF}\left(\mathrm{x}_{1}\right)$, however, while ash had a significant negative effect for linear term of HPMC $\left(\mathrm{x}_{2}\right), \mathrm{a}^{*}$ value had a significant negative effect of quadratic term of PDCF $\left(\mathrm{x}_{1}\right)$ (Table 2$)$. The chia seeds have a high content of minerals $(\mathrm{Ca}, \mathrm{P}, \mathrm{K}, \mathrm{Mg}, \mathrm{Fe}$, and $\mathrm{Zn}$ ) that contribute for ash content and is interesting for human nutrition (Silva et al., 2016).

For $\mathrm{L}^{\star}$ and $\mathrm{b}^{*}$ it was observed a similar behavior: negative effect of the linear HPMC term $\left(\mathrm{x}_{2}\right)$. An additional negative effect of quadratic PDCF term $\left(\mathrm{x}_{1}\right)$ was observed for $\mathrm{L}^{\star}$ (Table 2 ). Huerta et al. (2018) demonstrated that GFB with high values of $\mathrm{L}^{*}(\cong 80)$ and $\mathrm{b}^{*}(\cong 27)$, and lower values of $\mathrm{a}^{*}(\cong 0)$ ensure higher sensory acceptance for color attribute.

Valid linear models $\left(\mathrm{R}^{2} \geq 0.85 ; \mathrm{R}^{2}\right.$-adjusted $\left.\geq 0.79\right)$ were obtained for all the responses with significant effects $(\mathrm{p}<0.05)$ (Table 3 and Figure 1). The exception was the specific volume $\left(\mathrm{R}^{2}=0.45 ; \mathrm{R}^{2}\right.$-adjusted $\left.=0.35\right)$, thus this response surface was not generated. For all responses, non-significant effects were incorporated into the residue of the model, except in cases in which the effect influenced negatively the $\mathrm{R}^{2}$-adjusted.

The effects discussed next are based on the models individually developed for each response. Among the responses only carbohydrate and $\mathrm{a}^{\star}$ are interesting in lower values, and all other should be increased. For protein and omega-3 it was observed a similar behavior: positive linear and quadratic effects of the $\operatorname{PDCF}\left(\mathrm{x}_{1}\right)$. Additionally, for protein was observed a positive quadratic effect of HPMC $\left(\mathrm{x}_{2}\right)$. For ash and $\mathrm{a}^{*}$, it was observed a positive linear effect and a negative quadratic effect of PDCF $\left(x_{1}\right)$. In contrast, ash had a positive linear effect of $X G\left(x_{3}\right)$ and $\mathrm{a}^{*}$ had a positive quadratic effect of $\operatorname{HMPC}\left(\mathrm{x}_{2}\right)$. However, for fourth mentioned variables the linear effect of PDCF $\left(\mathrm{x}_{1}\right)$ 


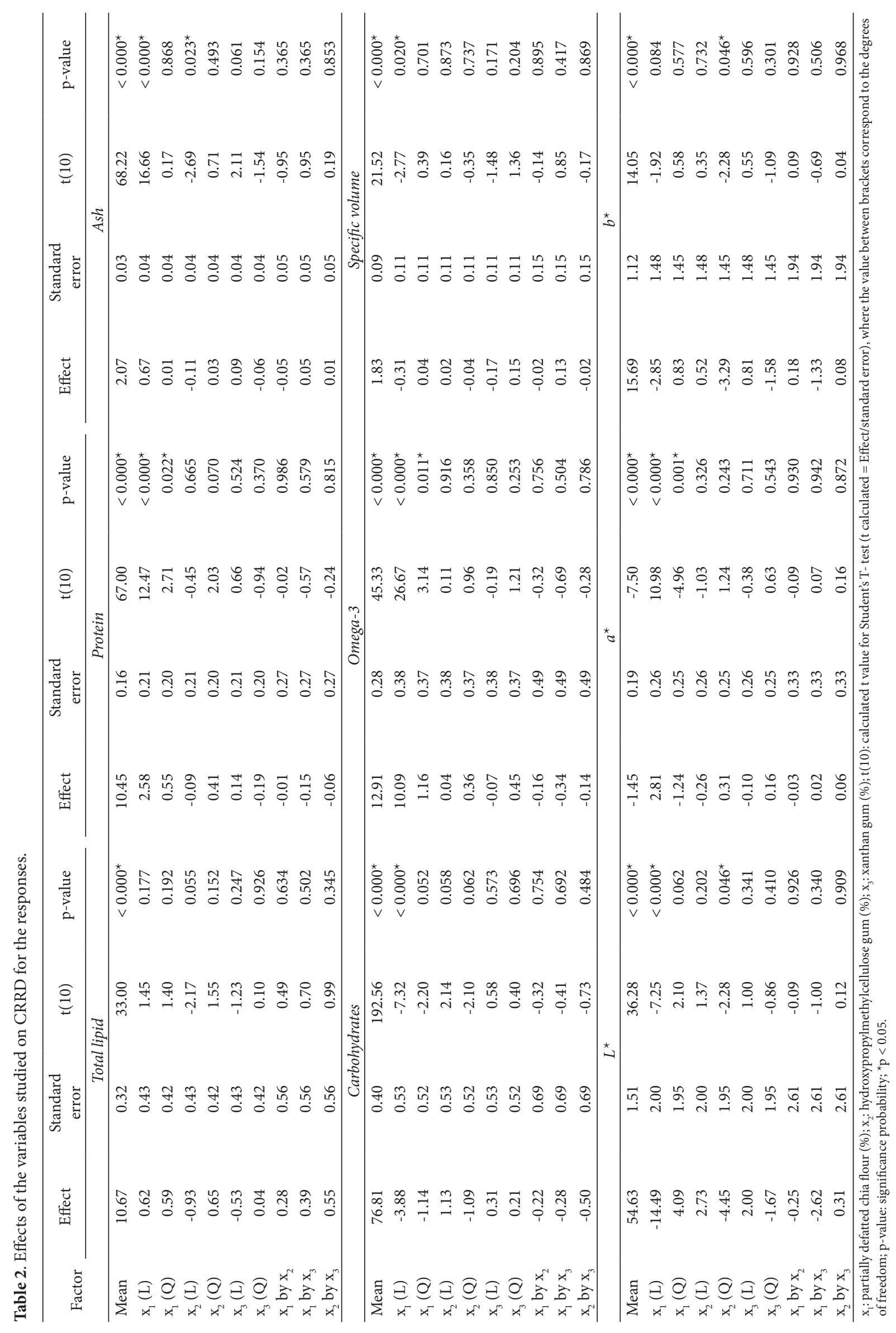


Table 3. Anova of CCRD models for the responses.

\begin{tabular}{|c|c|c|c|c|c|}
\hline CCRD response & F calculated & F tabulated & p-value & $\mathrm{R}^{2}$ & $\mathrm{R}^{2}$-adjusted \\
\hline Crude protein & 75.31 & 3.24 & $<0.000^{*}$ & 0.94 & 0.89 \\
\hline Ash & 102.71 & 3.24 & $<0.000^{*}$ & 0.95 & 0.94 \\
\hline Carbohydrates & 22.53 & 3.06 & $<0.000^{*}$ & 0.86 & 0.82 \\
\hline Omega-3 & 474.20 & 3.59 & $<0.000^{*}$ & 0.98 & 0.98 \\
\hline Specific volume & 3.50 & 2.96 & $0.029^{\star}$ & 0.45 & 0.35 \\
\hline $\mathrm{L}^{*}$ & 15.49 & 2.96 & $<0.000^{*}$ & 0.85 & 0.79 \\
\hline$a^{*}$ & 67.46 & 3.24 & $<0.000^{*}$ & 0.93 & 0.91 \\
\hline
\end{tabular}

CCRD: central composition rotatable design; F-calculated: calculated F for Anova (F-calculated = regression square mean / residuals square mean); F-tabulated: tabulated F for Anova; p-value: significance probability; $\mathrm{R}^{2}$ : determination coefficient; $\mathrm{R}^{2}$-adjusted: determination coefficient adjusted; ${ }^{*} \mathrm{p}<0.05$.
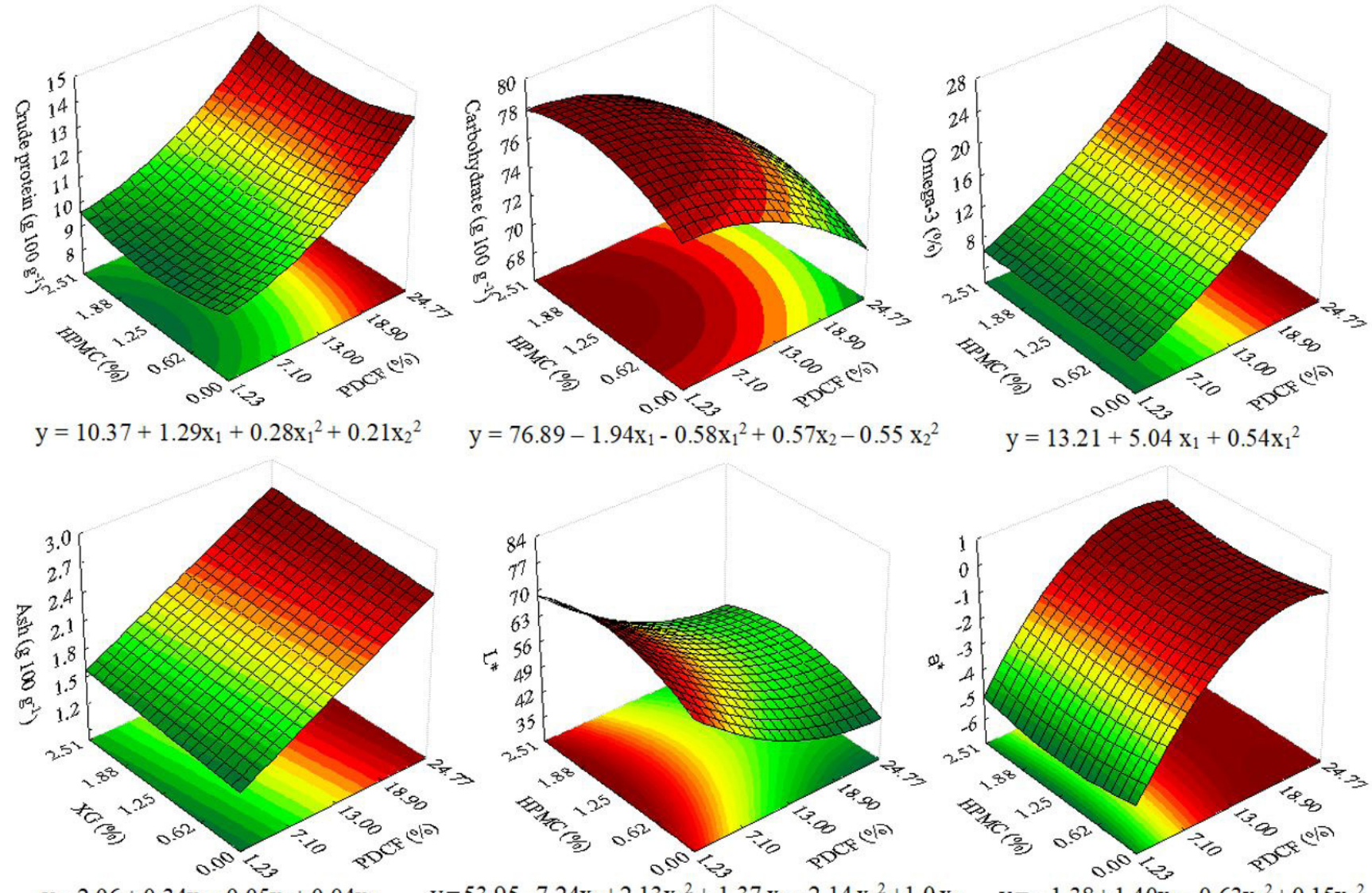

$\mathrm{y}=13.21+5.04 \mathrm{x}_{1}+0.54 \mathrm{x}_{1}^{2}$
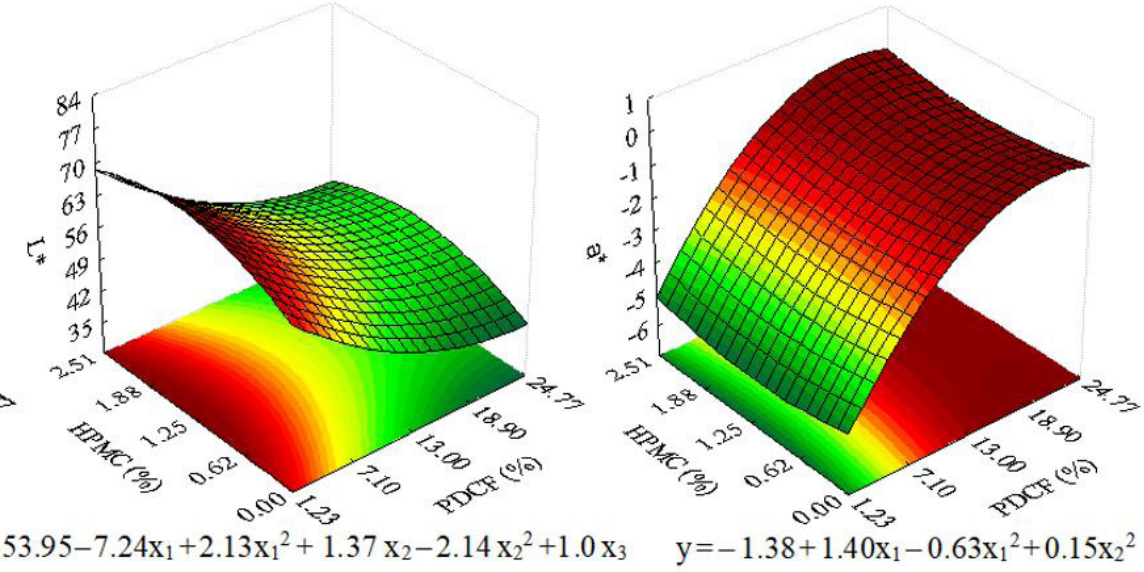

Figure 1. Response surface plots of responses. $x_{1}=\operatorname{PDCF}(\%) ; x_{2}=\operatorname{HPMC}(\%) ; x_{3}=X G(\%)$. PDCF: partially defatted chia flour; HPMC: hydroxypropylmethylcellulose gum; XG: xanthan gum.

influence numerically more the responses (Table 2 and Figure 1 ). For protein, ash and omega- 3 the high levels of PDCF $\left(\mathrm{x}_{1}\right)$ in CCRD (24.77\%) was favorable to increase the content, while for $\mathrm{a}^{\star}$ the lower level (1.23) was better because lower $\mathrm{a}^{*}$ was sensorially accepted (Huerta et al., 2018). Carbohydrate and L* had similar models, with negative linear effects of PDCF $\left(\mathrm{x}_{1}\right)$, and a positive linear and negative quadratic effect of $\operatorname{HPMC}\left(\mathrm{x}_{2}\right)$. An additional negative and positive quadratic effect of $\operatorname{PDCF}\left(\mathrm{x}_{1}\right)$ was observed for carbohydrates and $\mathrm{L}^{*}$, respectively. For both variables, the PDCF and HPMC influence the responses (Table 2 and Figure 1). For carbohydrate and $L^{\star}$ the high studied level of PDCF (24.77\%) was favorable to reduce the carbohydrates, while for $\mathrm{L}^{*}$ the central point level was the best to increase $\mathrm{L}^{*}(1.25)$, because consumers prefer lighter GFB (Huerta et al., 2018).

By desirability, high levels of PDCF should be applied to achieve healthy nutritional aspects of GFB, while the HPMC and XG had small influences in this approach (Figure 2).

In general, the GFB run 2 and run 1 had average grades $>6.2$ for all attributes, showing good acceptance (Table 4 ). The aroma and flavor had similar grades $(\mathrm{p}>0.05)$, indicating that all GFB were accepted. Regarding the texture, run 2 was more accepted than run 1 and control, and run 1 was also more accepted than control $(p<0.05)$. In contrast, for color the control was more 

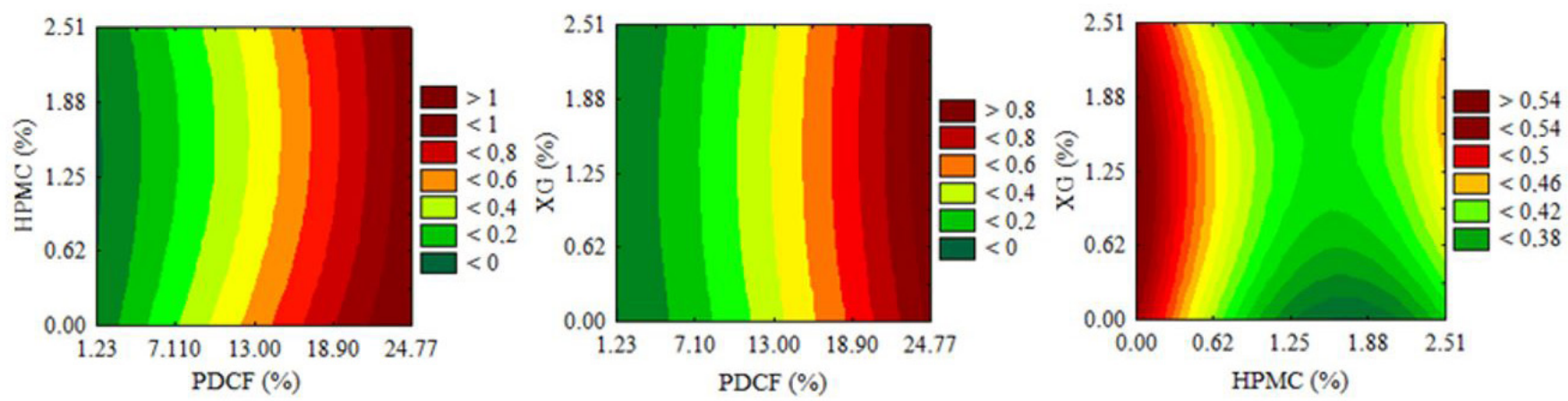

Figure 2. Desirability plot of variables with e nutritional aspects. PDCF: partially defatted chia flour; HPMC: hydroxypropylmethylcellulose gum.

Table 4. Sensory acceptance of gluten-free breads.

\begin{tabular}{lccc}
\hline \multicolumn{1}{c}{ Attributes } & Run 2 (PDCF 20\%) & Run 1 (PDCF 6\%) & Control (without PDCF) \\
\hline Aroma & $6.70 \pm 1.90^{\mathrm{a}}$ & $6.42 \pm 1.36^{\mathrm{a}}$ & $6.57 \pm 1.42^{\mathrm{a}}$ \\
Color & $6.20 \pm 1.80^{\mathrm{c}}$ & $6.92 \pm 1.69^{\mathrm{b}}$ & $7.54 \pm 1.93^{\mathrm{a}}$ \\
Texture & $6.91 \pm 1.66^{\mathrm{a}}$ & $6.29 \pm 1.66^{\mathrm{b}}$ & $4.81 \pm 1.80^{\mathrm{c}}$ \\
Flavor & $6.56 \pm 1.79^{\mathrm{a}}$ & $6.28 \pm 1.88^{\mathrm{a}}$ & $6.16 \pm 2.06^{\mathrm{a}}$ \\
Overall acceptance & $6.80 \pm 1.62^{\mathrm{a}}$ & $6.51 \pm 1.43^{\mathrm{ab}}$ & $6.08 \pm 1.76^{\mathrm{b}}$ \\
\hline
\end{tabular}

PDCF: partially defatted chia flour; Mean \pm standard deviation $(\mathrm{n}=116)$; different letters in the same line indicate significant differences $(\mathrm{p}<0.05)$.
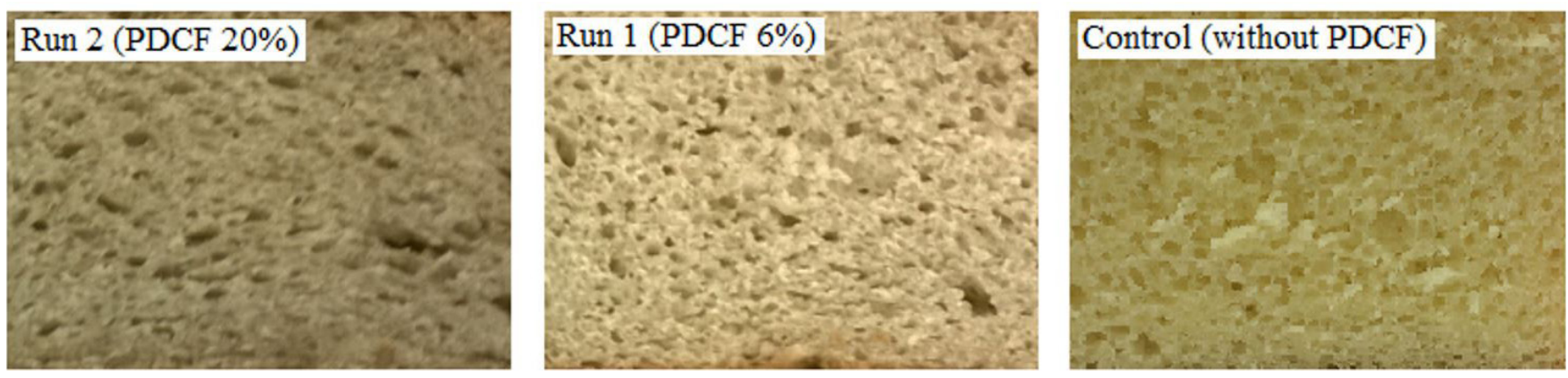

Figure 3. Gluten-free bread crumbs appearance and color. PDCF: partially defatted chia flour.

accepted, followed by run 1 and run 2, with significant differences among all $(\mathrm{p}<0.05)$. In Figure 3 the crumb color of GFB is showed. Similarly, Huerta et al. (2018) reported lower acceptance for GFB color elaborated with chia flour in comparison with a control (without chia flour). However, the overall acceptance of run 2 and 1 was higher than control $(\mathrm{p}<0.05)$, and between the GFB with PDCF the consumers preferred run 1 ( $\mathrm{p}<0.05)$. The greater overall acceptance of run 2 come to meet with the nutritional aspects incremented in this GFB. The use of sensory test on food product development have been indispensable, because is an efficient tool to obtaining information regarding consumer experience at consumption time (Costa et al., 2019; Iuliano et al., 2019). Moreover, some studies have been reported the description of different food employing projective methods, using words, phrases or figures in order to recognize consumers interpretation facing a stimulus (Gambaro, 2018); for example, in future studies, the use of words association may be high valuable for GFB sensory description using the analysis of chi-square statistic (Carabante \& Prinyawiwatkul, 2018; Judacewski et al., 2019), especially if combined with other sensory approach (e.g. acceptance) (Costa et al., 2019).

\section{Conclusion}

The PDCF was the variable with higher effect in responses studied in GFB formulations. The nutritional aspects were improved by PDMC addition in higher proportions (up to $24.77 \%$ in mixed flour), with an increase in protein, ash, and omega- 3 content, and a reduction in the carbohydrate content of GFB. In contrast, the PDCF addition in the higher proportions negatively influenced the color parameters; decreasing the value of $\mathrm{L}^{\star}$ and increasing the value of $\mathrm{a}^{*}$. However, despite the negative influence on color, the mixed flour formulation with $20 \%$ of PDCF, $0.51 \%$ of HMPC, and $0.51 \%$ of XG added to GFB was the most accepted for overall acceptance. The HPMC and XG had no effect on nutritional aspects of GFB, but in the percentage applied in samples sensorially evaluated $(0.51 \%)$ it improved the physical characteristics and the acceptance compared with control (without hydrocolloids).

\section{Acknowledgements}

Capes, CNPq, Fundação Araucária and Universidade Tecnológica Federal do Paraná. 


\section{References}

Alencar, M. L., Ortiz-Agostinho, C. L., Nishitokukado, I., Damiao, A. O., Abrantes-Lemos, C. P., Leite, A. Z., Brito, T., Chamone, D. A. F., Silva, M. E. R., Giannella-Neto, D., \& Sipahi, A. M. (2012). Prevalence of celiac disease among blood donors in São Paulo: the most populated city in Brazil. Clinics, 67(9), 1013-1018. http://dx.doi. org/10.6061/clinics/2012(09)05. PMid:23018296.

Assaad, M., El Mallah, C., \& Obeid, O. (2019). Phosphorus ingestion with a high-carbohydrate meal increased the postprandial energy expenditure of obese and lean individuals. Nutrition, 57, 59-62. http://dx.doi.org/10.1016/j.nut.2018.05.019. PMid:30153580.

Association of Official Analytical Chemists - AOAC. (1995). Official methods of analysis of the Association of Official Analytical Chemists (16th ed.). Washington: AOAC.

Bligh, E. G., \& Dyer, W. J. (1959). A rapid method of total lipid extraction and purification. Canadian Journal of Biochemistry and Physiology, 37(8), 911-917. http://dx.doi.org/10.1139/o59-099. PMid:13671378.

Brites, L. T. G. F., Ortolan, F., Silva, D. W., Bueno, F. R., Rocha, T. S., Chang, Y. K., \& Steel, C. J. (2019). Gluten-free cookies elaborated with buckwheat flour, millet flour and chia seeds. Food Science and Technology, 39(2), 458-466. http://dx.doi.org/10.1590/fst.30416.

Carabante, K. M., \& Prinyawiwatkul, W. (2018). Data analyses of a multiple-samples sensory ranking test and its duplicated test: a review. Journal of Sensory Studies, 33(4), e12435. http://dx.doi. org/10.1111/joss.12435.

Chaves, M. A., Souza, A. H. P., Colla, E., Bittenccourt, P. R. S., \& Matsushita, M. (2018). Influences of chia flour and the concentration of total solids on the characteristics of 'dulce de leche' from goat milk. Food Science and Technology, 38(Suppl. 1), 338-344. http:// dx.doi.org/10.1590/1678-457x.22017.

Costa, E. A., Sousa, P. H. M., Siqueira, A. C. P., Figueiredo, E. A. T., Gouveia, S. T., Figueiredo, R. W., Maia, C. S. C., \& Gomes, D. S. (2019). Fruit pastes with organic honey texturized with gellan gum: bioacessibility of antioxidant activity and sensory analysis fruit pastes with gellan and organic honey. Food Science and Technology, 39(3), 667-676. http://dx.doi.org/10.1590/fst.05518.

Costantini, L., Lukšič, L., Molinari, R., Kreft, I., Bonafaccia, G., Manzi, L., \& Merendino, N. (2014). Development of gluten-free bread using tartary buckwheat and chia flour rich in flavonoids and omega-3 fatty acids as ingredients. Food Chemistry, 165, 232-240. http://dx.doi. org/10.1016/j.foodchem.2014.05.095. PMid:25038671.

Crockett, R., Ie, P., \& Vodovotz, Y. (2011). How do xanthan and hydroxypropyl methylcellulose individually affect the physicochemical properties in a model gluten-free dough? Journal of Food Science, 76(3), E274-E282. http://dx.doi.org/10.1111/j.1750-3841.2011.02088.x. PMid:21535827.

El-Dash, A. A., Camargo, C. R. O., \& Diaz, N. (1982). Fundamentos de tecnologia de panificação (6. ed., Série Agro-Industrial). São Paulo: Coodenadoria da Indústria e Comércio.

Época. (2018, June 12). Brasileiro aumenta consumo de alimentos sem glúten e lactose. Retrieved from https://epocanegocios.globo.com/ Economia/noticia/2018/06/brasileiro-aumenta-consumo-dealimentos-sem-gluten-e-lactose.html

Ewerlin, M., Bortolatto, R., Torquato, A. S., Steinmacher, N. C., \& Rodrigues, A. C. (2018). Composição proximal e de ácidos graxos da farinha de chia (Salvia hispanica) parcialmente desengordurada. Revista Virtual de Química, 10(1), 13-20. http://dx.doi.org/10.21577/19846835.20180003.

Faccim, A. G., Silva, L. A. A., Sant'Ana, M. R., Grancieri, M., Costa, A. G. V., \& Cintra, D. E. C. (2016). Funcionalidade dos ácidos graxos.
In N. M. B. Costa \& C. O. B. Rosa (Eds.), Alimentos funcionais componentes bioativos e efeitos fisiológicos (2. ed., Cap. 3, pp. 29-47). Rio de Janeiro: Rubio.

Gambaro, A. (2018). Projective techniques to study consumer perception of food. Current Opinion in Food Science, 21, 46-50. http://dx.doi. org/10.1016/j.cofs.2018.05.004.

Hartman, L., \& Lago, R. C. A. (1973). Rapid preparation of fatty acid methyl esters from lipids. Laboratory Practice, 22(6), 475-476. PMid:4727126.

Huerta, K. M., Alves, J. S., Silva, A. F. C., Kubota, E. H., \& Rosa, C. S. (2016). Sensory response and physical characteristics of gluten-free and gum-free bread with chia flour. Food Science and Technology, 36(Suppl. 1), 15-18. http://dx.doi.org/10.1590/1678-457x.0032.

Huerta, K. M., Boeira, C. P., Soquetta, M. B., Alves, J. S., Kubota, E. H., \& Rosa, C. S. (2018). The effect of chia (Salvia hispanic L.) flour as a substitute for fat in gluten-free bread. Nutrition \& Food Science. In press. http://dx.doi.org/10.1108/NFS-08-2018-0240.

Huerta, K., Soquetta, M., Alves, J., Stefanello, R., Kubota, E., \& Rosa, C. S. (2017). Effect of flour chia (Salvia hispanica L.) as a partial substitute gum in gluten free breads. International Food Research Journal, 25(2), 755-761.

Iuliano, L., González, G., Casas, N., Moncayo, D., \& Cote, S. (2019). Development of an organic quinoa bar with amaranth and chia. Food Science and Technology, 39(Suppl. 1), 218-224. http://dx.doi. org/10.1590/fst.25517.

Judacewski, P., Los, P. R., Lima, L. S., Alberti, A., Zielinski, A. A. F., \& Nogueira, A. (2019). Perceptions of Brazilian consumers regarding white mould surface-ripened cheese using free word association. International Journal of Dairy Technology, 72(4), 585-590. http:// dx.doi.org/10.1111/1471-0307.12649.

Pereira, B. S., Pereira, B. S., Cardoso, É. S., Mendonça, J. O. B., Souza, L. B., Santos, M. P., Zago, L., \& Freitas, S. M. L. (2013). Análise físicoquímica e sensorial do pão de batata isento de glúten enriquecido com farinha de chia. Demetra: Alimentação, Nutrição e Saúde, 8(2), 125-136. http://dx.doi.org/10.1016/j.jprot.2011.05.023.

Resende, P. V. G., Silva, N. L. M., Schettino, G. C. M., \& Liu, P. M. F. (2017). Brasileiro aumenta consumo de alimentos sem glúten e lactose. Revista Médica de Minas Gerais, 27(Suppl. 3), S51-S58.

Silva, B. P., Cardoso, L. M., Della Lucia, C. M., Martino, H. S. D., \& Sant'Ana, H. M. P. (2016). Chia: aspectos nutricionais e funcionais. In N. M. B. Costa \& C. O. B. Rosa (Eds.), Alimentos funcionais componentes bioativos e efeitos fisiológicos (2. ed., Cap. 15, pp. 209216). Rio de Janeiro: Rubio.

Steffolani, E., De la Hera, E., Pérez, G., \& Gómez, M. (2014). Effect of chia (Salvia hispanica L.) addition on the quality of glutenfree bread. Journal of Food Quality, 37(5), 309-317. http://dx.doi. org/10.1111/jfq.12098.

Veggi, N., Voltarelli, F. A., Pereira, J. M. N., Silva, W. C., Navalta, J. W., Cavenaghi, D. F. L. D. C., \& Barros, W. M. (2018). Quality of high-protein diet bar plus chia (Salvia hispanica L.) grain evaluated sensorially by untrained tasters. Food Science and Technology, 38(Suppl. 1), 306-312. http://dx.doi.org/10.1590/fst.22317.

Wang, K., Lu, F., Li, Z., Zhao, L., \& Han, C. (2017). Recent developments in gluten-free bread baking approaches: a review. Food Science and Technology, 37(Suppl. 1), 1-9. http://dx.doi.org/10.1590/1678457x.01417.

Zettel, V., \& Hitzmann, B. (2018). Applications of chia (Salvia hispanica L.) in food products. Trends in Food Science \& Technology, 80, 43-50. http://dx.doi.org/10.1016/j.tifs.2018.07.011. 